\title{
THE ROLE OF THE TROPICAL ATLANTIC AND PACIFIC OCEANS SST IN MODULATING THE RAINFALL OF PARAÍBA STATE, BRAZIL
}

\author{
Célia Campos Braga ${ }^{1}$, Jonathan Castro Amanajás ${ }^{1}$, \\ Hallan David Velasco Cerqueira ${ }^{2}$ and Maria Isabel Vitorino ${ }^{3}$
}

\begin{abstract}
A diagnostic analysis of monthly precipitation (PRP) was realized for the state of Paraíba, Brazil, to correlate it with the sea surface temperature (SST) in the monitoring regions of the Equatorial Pacific and Tropical Atlantic, from 1962 to 2007. To this end, the techniques of Wavelet Transform (WT) and linear correlation analysis were used. The results obtained by the WT technique for both PRP and SST have shown that the overall energy spectrum of the wavelet is most striking in the annual cycle. For PRP, beyond the annual scale, complex interactions of oscillations in different time scales can be observed, such as monthly, intraseasonal, semiannual, biennial and decadal. The analysis of the Pacific SST shows that the annual scale is more intense in the eastern part of the ocean, decreasing from east to west, where the decadal scale becomes more pronounced. The analysis of the Atlantic SST indicated basically two variations: one, annual and another, decadal. The Pacific SST correlated better with the PRP observed on the coast of Paraíba, and the Atlantic Dipole with the rains in the state western region.
\end{abstract}

Keywords: wavelet transforms, homogeneous region, ENSO, Atlantic Dipole.

RESUMO. Neste estudo foi realizada uma análise diagnóstica da precipitação mensal (PRP) para o Estado da Paraíba, relacionando-a com a temperatura da superfície do mar (TSM), nas regiões de monitoramentos do Pacífico Equatorial e Atlântico Tropical, para o período de 1962 a 2007. Para isso, utilizaram-se as técnicas da Transformada em Ondeletas (TO) e análise de correlação linear. Os resultados encontrados da aplicação da T0, tanto na PRP como na TSM, mostraram que 0 espectro global de energia da ondeleta é mais marcante no ciclo anual. Para a PRP, além da escala anual, podem-se observar interações complexas de oscilações em diferentes escalas de tempo, tais como: mensal, intrasazonal, semianual, bianual e decadal. A análise da TSM do Pacífico apresentou escala anual mais intensa na parte leste do oceano, decrescendo no sentido leste-oeste, onde a escala decadal se torna mais acentuada. A análise da TSM do Atlântico indicou basicamente duas oscilações: uma na escala anual e outra na escala decadal. A TSM do Pacífico relacionou-se melhor com a PRP observada no litoral paraibano, e o Dipolo do Atlântico (DPA) com as chuvas na parte oeste do Estado.

Palavras-chave: transformada em ondeletas, regiões homogêneas, ENOS, Dipolo do Atlântico.

\footnotetext{
1 Departamento de Ciências Atmostéricas, Universidade Federal de Campina Grande, Rua Aprígio Veloso, 882, Bloco CL, Bairro Universitário, P.0. Box 10041, 58429-900 Campina Grande, PB, Brazil. Phone/Fax: +55(83) 2101-1202 - E-mails: celia@dca.ufcg.edu.br; jonathan.amanajas@hotmail.com

${ }^{2}$ Núcleo Geoambiental, Universidade Estadual do Maranhão, Cidade Universitária Paulo VI, s/n, Cidade Operária, P.0. Box 09, 65054-970 São Luís, MA, Brazil. Phone/Fax: +55(98) 3244-0915 - E-mail: hdmeteorologia@gmail.com

3 Faculdade de Meteorologia, Universidade Federal do Pará, Rua Augusto Corrêa, 1, Guamá, P.0. Box 479, 66075-110 Belém, PA, Brazil. Phone: +55(91) 3201-7107; Fax: +55(91) 3201-7609 - E-mail: vitorino@ufpa.br
} 


\section{INTRODUCTION}

Currently, the general weather conditions in Northeastern Brazil (NEB), are well known and studied both from a statistical and physical perspective. Nevertheless, it is still necessary to investigate further the relationships between changing sea surface temperature (SST) of the Equatorial Pacific and Atlantic oceans and the rainfall in Paraíba state, Brazil.

Meteorological studies show that the average rainfall decreases rapidly from the eastern towards the central region of the state, and then gradually increases towards the western end of the state (Brito \& Braga, 2005). According to Nimer (1979), this trend results from the way mesoscale systems move and enter the states of Pernambuco and Paraíba. Thus, global-scale systems such as the Intertropical Convergence Zone (ITCZ) and the synoptic scale, like the Eastern waves, Frontal System and Upper Tropospheric Cyclonic Vortex (UTCV), are the main causes of disturbances in weather precipitation in NEB. This region is the end point of several of these atmospheric circulation systems, which, when passing, cause instability and precipitation (Nimer, 1972; Kousky, 1979; Kousky, 1980; Hastenrath \& Greishar, 1993; Rao et al., 1993; Braga et al., 2003).

Most of these precipitation systems acting on NEB are directly influenced by the sea surface temperature (SST) of the two adjacent oceans. The El Niño - Southern Oscillation (ENSO) cycle on the Equatorial Pacific, characterized by extreme SST anomalies situated almost zonally in the eastern Equatorial $\mathrm{Pa}$ cific, which are related to the weaker (stronger) trade winds in the western portion than normal during warm (cold) episodes. And, the phases of the meridional and inter-hemispheric gradient of the Tropical Atlantic SST anomalies, or Atlantic Dipole (Nobre \& Shukla, 1996; Souza et al., 1997; Souza et al., 2000; Pezzi \& Cavalcanti, 2001).

The Atlantic Dipole influences the north-south displacement of the ITCZ, which is the main weather system causing rains in the northeastern semi-arid during the rainy season (Uvo, 1989). The ITCZ main axis tends to position itself over the region to where the thermal gradient is directed. In the positive (negative) phase of the dipole, the thermal gradient points to the Northern (Southern) Hemisphere, and consequently, the positive precipitation anomalies associated with the ITCZ position themselves predominantly to the north (south) of the Equator (Hastenrath \& Greichscar, 1993; Sousa et al., 1997).

In recent years several statistical techniques have been introduced in meteorological studies, aiming at providing data for the characterization of nonlinear atmospheric regimes linked to the nature of its variables (Lau \& Weng, 1994; Vitorino et al., 2006).
This study investigated the SST variability in the Equatorial Pacific and Atlantic oceans and correlated it with the seasonal and interannual rainfall in Paraíba state. The Morlet Wavelet Transform technique was used to analyze the atmospheric signal over time from 1962 to 2007, with the objective of improving the numerous studies of NEB, and particularly for Paraíba state.

\section{MATERIALS AND METHODS}

\section{Study Area}

The Paraíba state covers approximately $56,584 \mathrm{~km}^{2}$ of the Brazilian territory, with 223 municipalities and an estimated population of 3,769,977 inhabitants. It is located on the eastern edge of Northeastern Brazil (NEB) and about $98 \%$ of its area is inside the drought polygon. Figure 1 shows the three locations representative of homogeneous rainfall regions in Paraíba chosen for the study: João Pessoa (coastal), Patos (hinterland) and Cajazeiras (high hinterland), according to Brito \& Braga (2005).

\section{Used Data}

The monthly precipitation (PRP) data from January 1962 to December 2007 were provided by the Departamento de Ciências Atmosféricas (DCA) of the Universidade Federal de Campina Grande (UFCG) and Agência Executiva de Gestão das Águas do Estado da Paraíba (AESA). The SST data from monitoring areas of Equatorial Pacific (Niño1+2, Niño 3, Niño 3.4 and Niño 4) and the Tropical Atlantic, for the same period, were obtained directly from the National Centers for Environmental Prediction/National Center for Atmospheric Research (NCEP/NCAR), as described in Reynolds et al. (2002) and indicated in Figure 2.

\section{Methodology}

The wavelet transform technique (WT) was used to analyze precipitation and SST, as proposed in the literature by various authors: Meyer (1993); Weng \& Lau (1994); Torrence \& Compo (1998); Morettin (1999); Vitorino (2002); Vitorino et al. (2006) and Bolzan (2006). This technique allows decomposing a time series into different levels of time-frequency or time-scale resolution for determining the dominant components of variability. This technique is needed because the precipitation (PRP) and SST time series have no seasonal characteristics (Bolzan, 2006). The term wavelet refers to the set of functions in the form of small waves generated by expansion and contraction of a function $\Phi(t)$ of a real variable $t$, denoted sometimes as mother wavelet.

The MATLAB $6.5^{\circledR}$ software was used to perform mathematical calculations and prepare the scalogram of the Morlet wavelet energy in time-scale, using the algorithms described by Torrence 


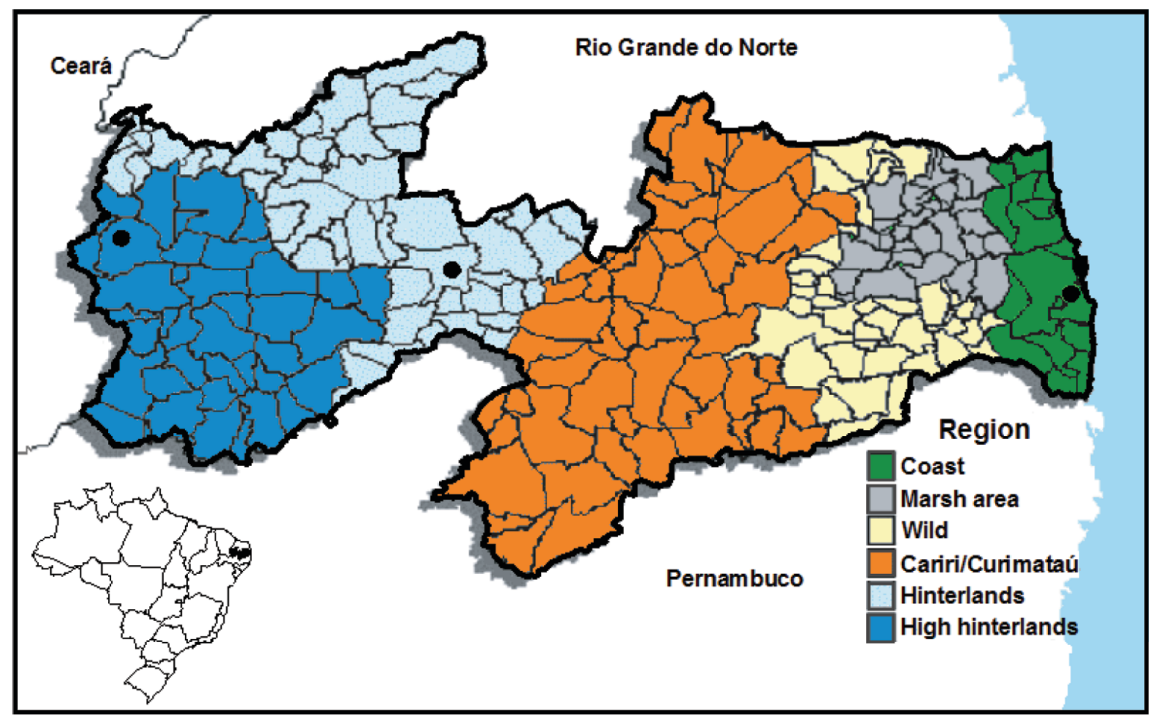

Figure 1 - Map of homogeneous rainfall regions of Paraíba, showing João Pessoa, Patos and Cajazeiras. Adapted from Brito et al., 2004.

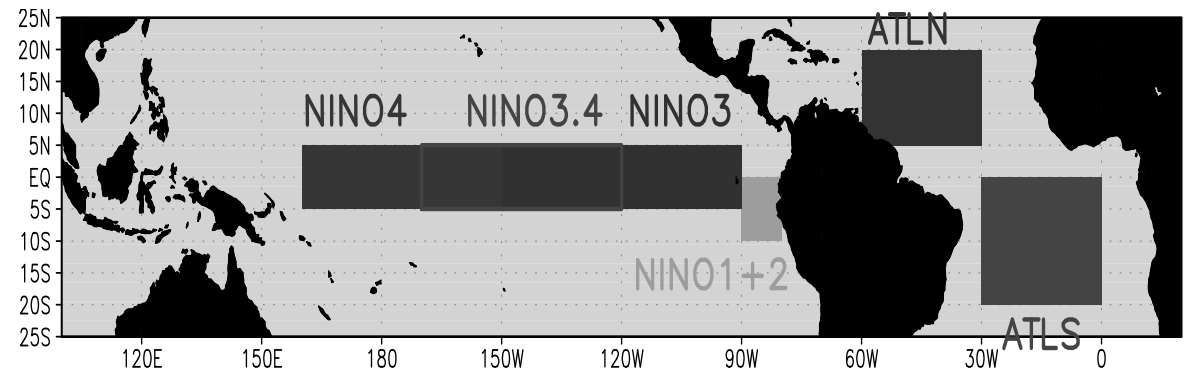

Figure 2 - SST monitoring regions in the Equatorial Pacific and Atlantic oceans. Source: Cerqueira, 2007.

\& Compo (1998), and Microsoft Office Excel $2007{ }^{\circledR}$ to determine the linear correlation between variables.

\section{Dipole Atlantic Calculation}

The years corresponding to either positive or negative dipole events were chosen based on the index proposed by Servain (1991). This index is given by the difference between the normalized North and normalized South Atlantic normalized SST anomalies, a positive (negative) dipole corresponded to index values above (below) $0.5^{\circ} \mathrm{C}$ for at least two consecutive months between January and June.

\section{Determination of El Niño and La Niña years}

The El Niño (EN) and La Niña (LN) years were classified according to the methodology described by Trenberth (1997), which consists of using SST anomalies (SSTA) data in the Niño 3.4 area. According to this methodology, the monthly moving averages of SSTA are analyzed for 5 months. The period is classified as EN (LN) event when this average is higher (lower) than $0.4^{\circ} \mathrm{C}\left(-0.4^{\circ} \mathrm{C}\right)$ for 6 months or longer. The episodes classification in the weak, moderate and strong categories is based on the work of Rasmusson \& Carpenter (1982) and Ropelewski \& Halpert (1989). Table 1 shows the classification of ENSO periods from 1962 to 2007.

\section{RESULTS AND DISCUSSION}

To analyze the SST and precipitation signal is necessary to focus on the scalogram, the graphical representation of wavelet energy coefficients, which allows detecting singularities in the time series as well as events that repeat over time. The largest amounts of wavelet energy in the SST and precipitation series are shown in red and orange contours in energy scalograms. The black coneshaped curve in the scalograms, called cone of influence, is the region of the wavelet spectrum in which the coefficients analysis changes due to function decay at the beginning and end of time series in the low frequency areas. Table 2 shows the time scales used in energy scalograms. 
Table 1 - Classification of El Niño and La Niña years, according to Trenberth (1997).

\begin{tabular}{|c|c|c|c|c|c|}
\hline \multicolumn{3}{|c|}{ El Niño Events } & \multicolumn{3}{|c|}{ La Niña Events } \\
\hline Start & End & $\begin{array}{c}\text { Lasted } \\
\text { (months) }\end{array}$ & Start & End & $\begin{array}{c}\text { Lasted } \\
\text { (months) }\end{array}$ \\
\hline Jun/63 & Feb/64 & 9 & Aug/62 & Feb/63 & 7 \\
May/65 & Jun/66 & 14 & Mar/64 & Jan/65 & 11 \\
Oct/68 & Apr/70 & 19 & May/70 & Jan/72 & 21 \\
Mar/72 & Mar/73 & 13 & Apr/73 & May/74 & 14 \\
Aug/76 & Mar/77 & 8 & Jul/74 & Jun/76 & 24 \\
Apr/82 & Jun/83 & 15 & Sept/84 & Jun/85 & 10 \\
Jul/86 & Feb/88 & 20 & Mar/88 & Jun/89 & 16 \\
Apr/91 & Jul/92 & 16 & Aug/95 & Mar/96 & 8 \\
Feb/93 & Aug/93 & 7 & Jun/98 & Jun/00 & 25 \\
Sept/94 & Apr/95 & 8 & Aug/00 & Feb/01 & 7 \\
\cline { 4 - 5 } Apr/97 & May/98 & 14 & \multicolumn{3}{|c|}{ Legend } \\
\hline May/02 & Mar/03 & 11 & \multicolumn{3}{|c|}{ Strong } \\
Jun/03 & Jun/04 & 13 & \multicolumn{3}{|c|}{ Moderate } \\
\cline { 4 - 5 } Jul/06 & Jan/07 & 7 & \multicolumn{3}{|c|}{ Weak } \\
\cline { 5 - 6 }
\end{tabular}

Table 2 - Timescales used in wavelet energy scalograms.

\begin{tabular}{|c|c|c|}
\hline Scale & Name & Length (months) \\
\hline$<0.25$ & Intraseasonal & between 1 and 2 months \\
0.25 & Seasonal & 3 months \\
0.5 & Semi-annual & 6 months \\
1 & Annual & 12 months \\
2 & Biennial & 24 months \\
4 & 4 years & 48 months \\
$>8$ years & Decadal & between 96 and 192 months \\
\hline
\end{tabular}

\section{Time-scale analysis of precipitation}

The WT analysis applied to the rainfall series for the city of João Pessoa has a dominant annual scale, as seen in Figure 3b. In 1965, the highest energy of precipitation is associated with this scale, as well as connections to major and minor scales, with the highest rainfall volume of about $731.0 \mathrm{~mm}$ recorded in July (Fig. 3a). High energy oscillations are observed associated with the time scales, biennial and 4 to 8 years. Among the cities studied, João Pessoa had the rainfall annual cycle with the greatest energy amplitude, approximately $2.5 \times 10^{5} \mathrm{~mm}^{2}$ (Fig. $3 \mathrm{c}$ ). In this region, the WT technique evidenced the influence of synoptic scale physical phenomena associated with seasonal and annual variations, such as: Eastern Waves and UTCV (Nimer 1972; Nimer 1979; Kousky, 1980; Rao et al., 1993; Vitorino et al., 2006).

Figure $4 \mathrm{~b}$ shows the Wavelet scalogram for Patos where the most intense energy spectrum is observed in 1965. In addition to the annual scale, there is also a strong association with the semi- annual, seasonal and intraseasonal scales. The highest rainfall of $486.7 \mathrm{~mm}$ was recorded In April 1965, followed by $463.5 \mathrm{~mm}$ in April 1967. In 1981, the $400 \mathrm{~mm}$ precipitation recorded in March caused more intense semi-annual and seasonal scales. During the 80s, the high energy in the scalogram between 4 and 8 years are related to the ENSO phenomenon. During 1984, 1985 and 1986, the annual scale shows a strong core of well-defined energy and a little interaction with the semi-annual scale in 1986 (Fig. 4b). The 90s show discontinuity in the annual energy scale, however, some settings in the semi-annual scale are quite evident in between 1991 and 1995; 1997 and 1998, with significant variability of monthly rainfall in this decade (Fig. 4a).

Figure $5 c$ shows the global energy wavelet spectrum for $\mathrm{Ca}-$ jazeiras. It is observed that the highest wavelet energy of rainfall predominates in the annual scale. The two highest rainfalls of 549.9 and $547.8 \mathrm{~mm}$ were recorded in April 1973 and March 1981, respectively, as seen in Figure 5a. The wavelet scalogram shows intense energy associated with annual scale, whose interaction with the energy core between the semi-annual and intraseasonal scales culminated in the event of April 1973 (Fig. 5b). The interactions between scales shorter than the annual are more evident, especially among semi-annual, seasonal and intraseasonal. The year of 1981 represents the end of the interaction between the annual and semi-annual scales, leading to the conclusion that the annual cycle is more relevant to the rainfall in Cajazeiras. Another isolated event that stood out due to the intense energy associated with the annual cycle happened in 1985, with the core in the 4-year scale and precipitation peak in April. 

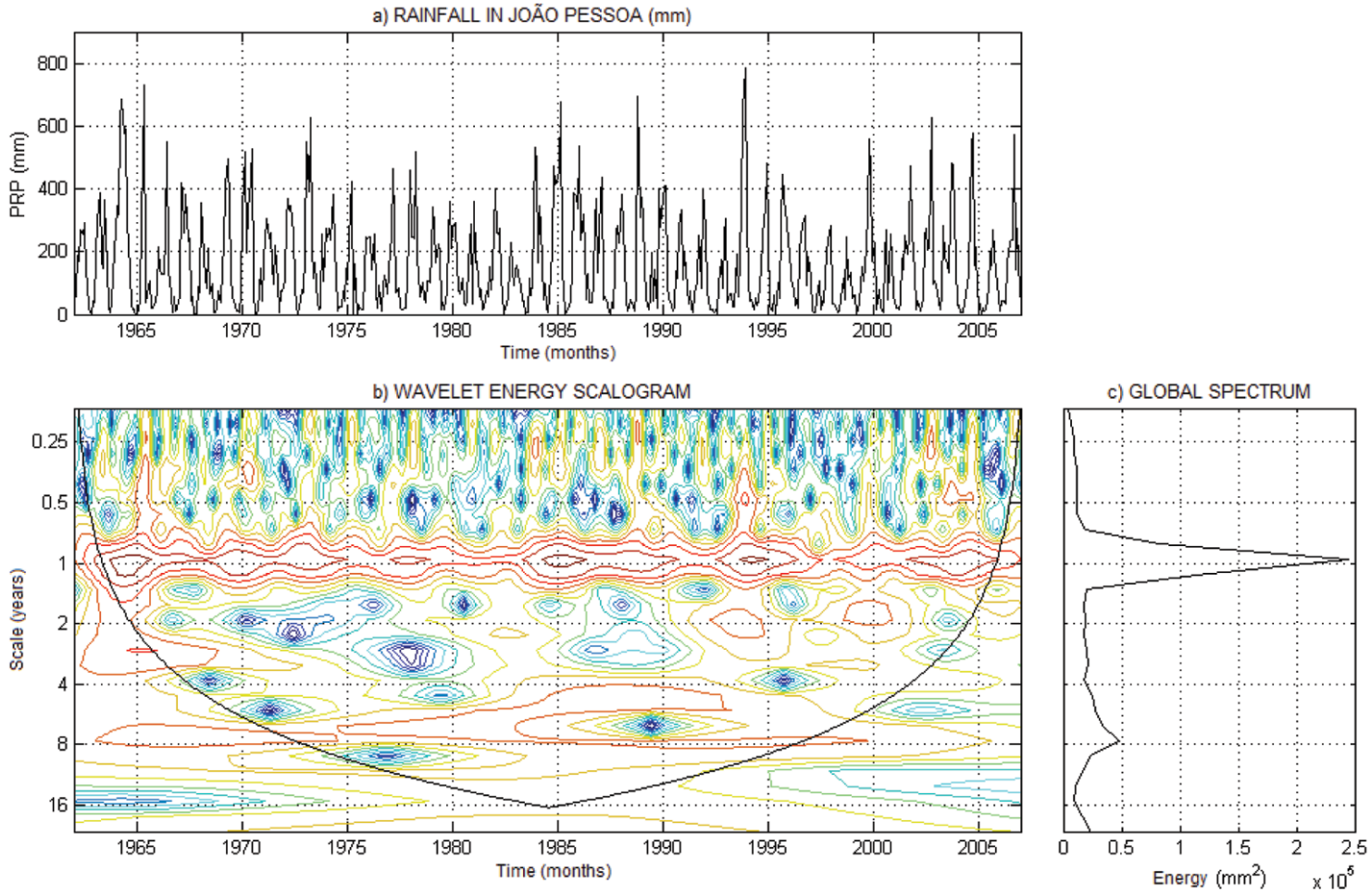

Figure 3 - Wavelet transform applied to rainfall. a) rainfall time series, b) wavelet energy scalogram, and c) overall spectrum for João Pessoa.
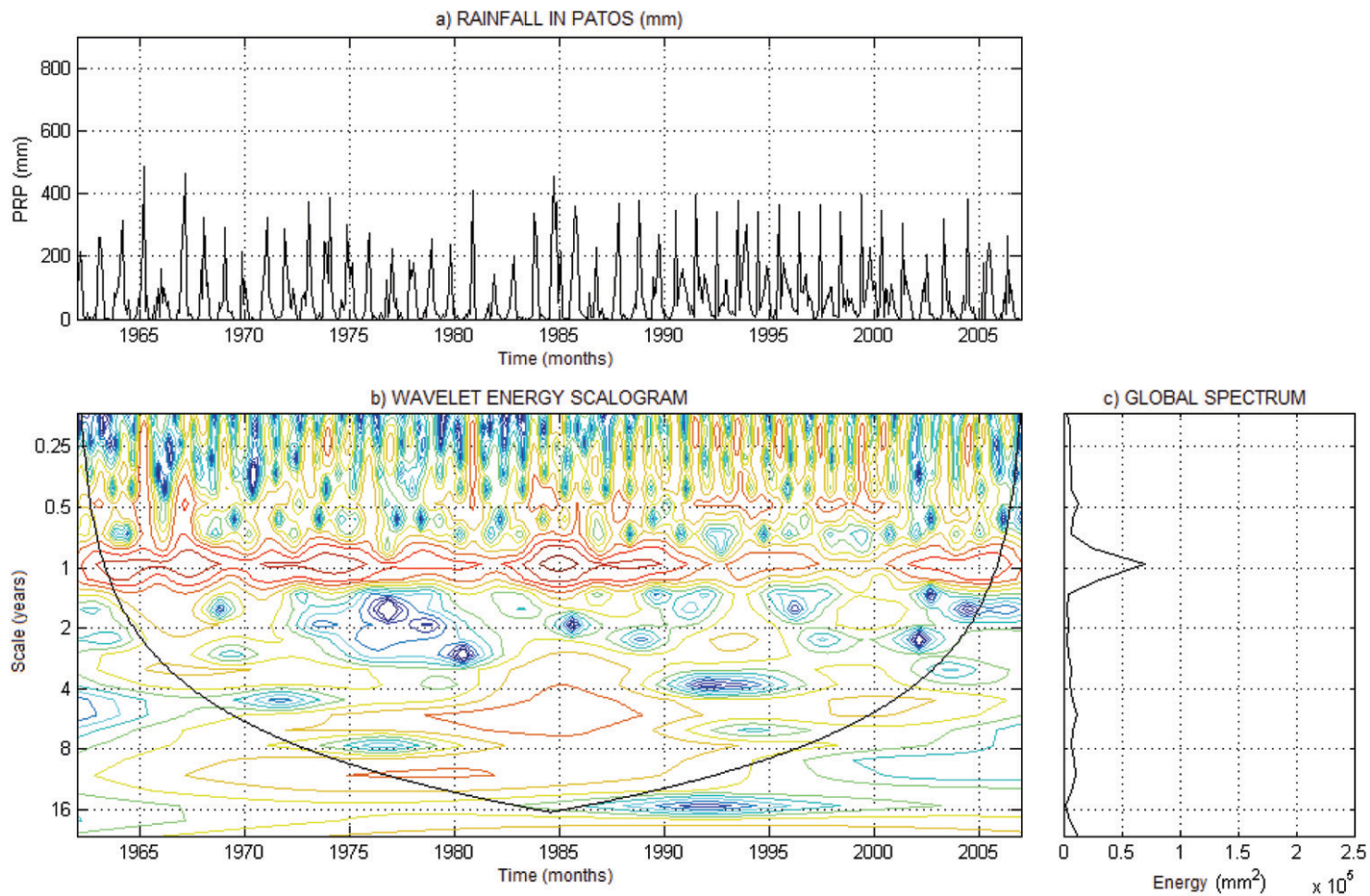

Figure 4 - Wavelet transform applied to rainfall. a) rainfall time series, b) wavelet energy scalogram, and c) overall spectrum for Patos. 

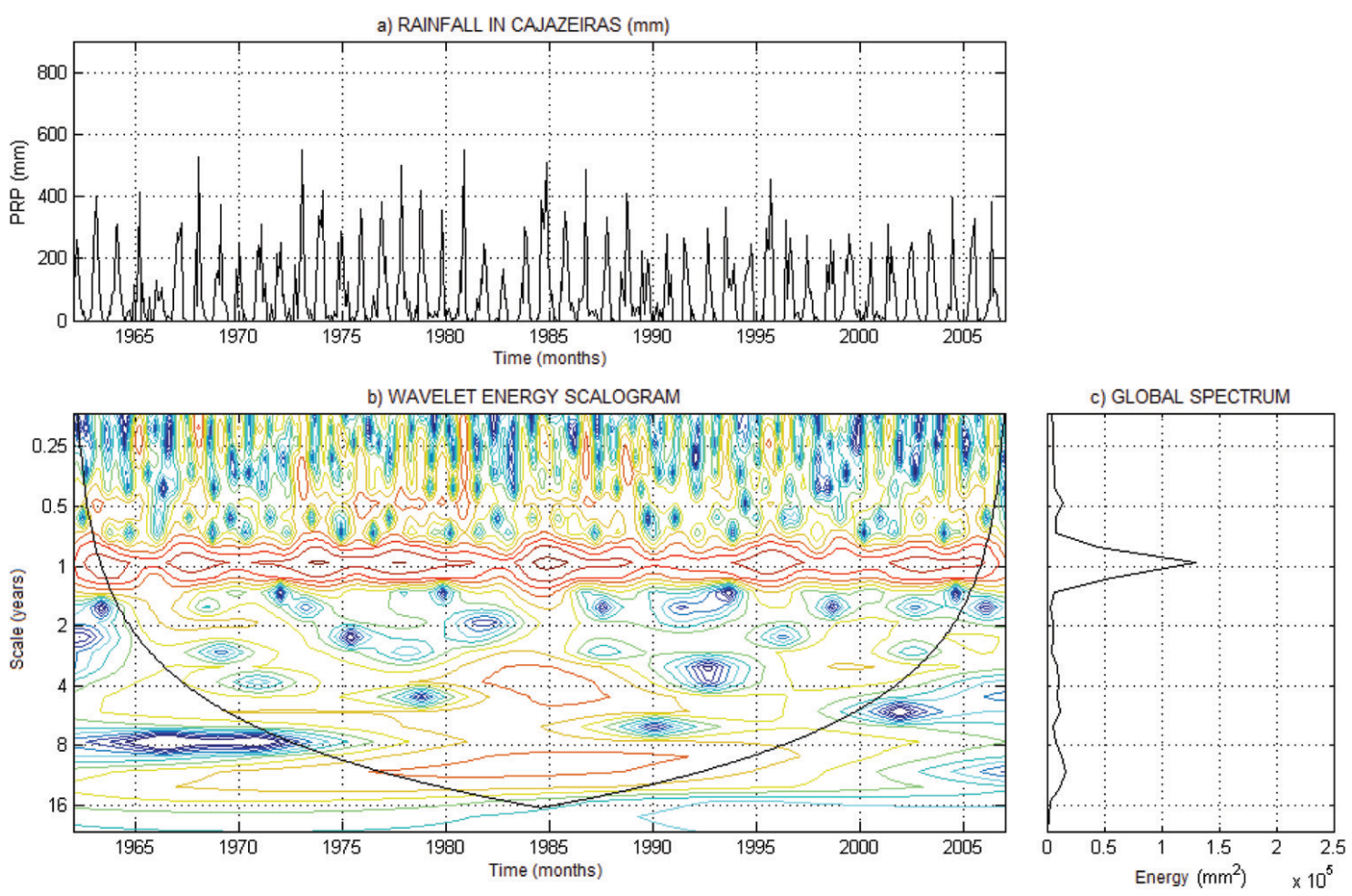

Figure $\mathbf{5}$ - Wavelet transform applied to rainfall. a) rainfall time series, b) wavelet energy scalogram, and c) overall spectrum for Cajazeiras.

\section{SST time-scale analysis}

The Niño $1+2$ region has the highest SST annual variability, so a large amount of energy is observed in the global spectrum associated with this scale (Fig. 6.1c). A significant amount of energy is also observed in the 4-year scale and in smaller proportion, in the biennial scale. The wavelet energy in the four-year scale, seen in Figure 6.1b, shows the highest values of SST between 1967 and 1973, and 1982/83 (1982/83, for example, was classified as strong El Niño event). This same scale also indicates the El Niño occurrence in 1992/93. Other interactions between the biennial and 4-year scales are also observed. The El Niño in 1997/98 also appears well defined between the biennial and decadal scales.

The Niño 3 region has different energy configuration, where the largest global energy is observed in the 4-year scale, followed by annual and biennial (Fig. 6.2c). Therefore, the configurations among scales in this region are quite chaotic. Still, some cases are noteworthy for the interaction between the 4-year, biennial and annual scales observed in the years 1982/83, 1987/88 and 1997/98, when the greatest variations of SST were also recorded (Fig. 6.2a).

The Niño 3.4 region shows a weakening in the annual scale (Fig. 6.3c). In this region of the Equatorial Pacific, the energy scalogram shows evidence of the interaction between the 4-year and the decadal scales (Fig. 6.3b). This region is very similar to the Niño 3 region, but the strengthening of the decadal and especially the 4-year scale is observed. The weakening of the annual scale might be associated with low annual SST variability that weakens the westward signal of the Equatorial Pacific (Fig. 6.3a), in which the 4-year and decadal cycles are more important than the Niño $1+2$ and 3 . This scalogram is very similar to that obtained by Torrence \& Compo (1998).

The annual scale weakens or simply ceases to exist in the Niño 4 region. It is suggested that this region has low annual SST variability, that is, the thermal variation throughout the year is almost constant (Fig. 6.4a). On the other hand, the decadal scale strengthens and interacts with the 4-year scale, indicating that these scales oscillations are more common in this Pacific region, as shown in Figure 6.4b. This leads us to conclude that the region has little or no relation to the EN events already recorded, which is in agreement with the reports of Trenberth (1997), Oliveira (1999) and Cerqueira (2007).

Figure 7.1c shows that in the North Atlantic the global energy spectrum has a more pronounced annual scale, but not very intense. As a result, the annual SST cycle is almost constant, although the entire range of energy concentrations is detected in the decadal scale. This indicates that a wave in such a scale is part of the construction of the series. The fact that higher energies are concentrated on the annual scale shows that the SST 

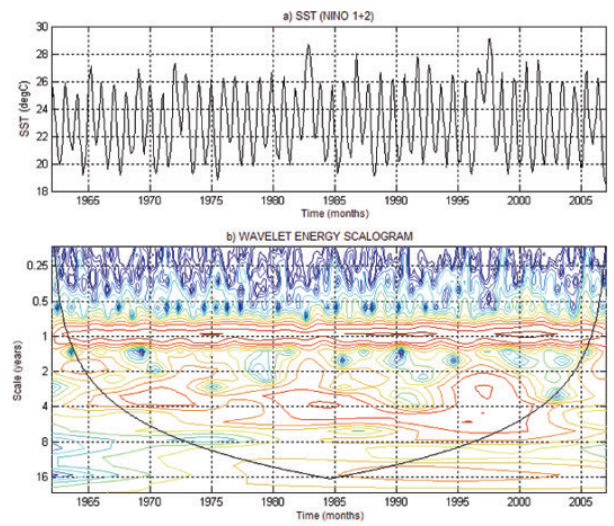

(1)
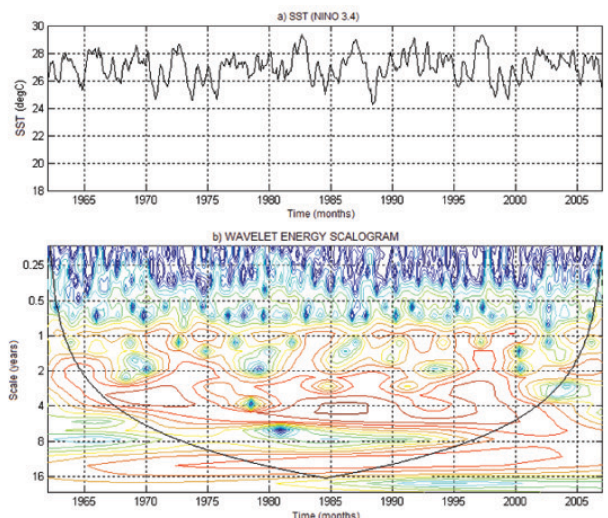

(3)
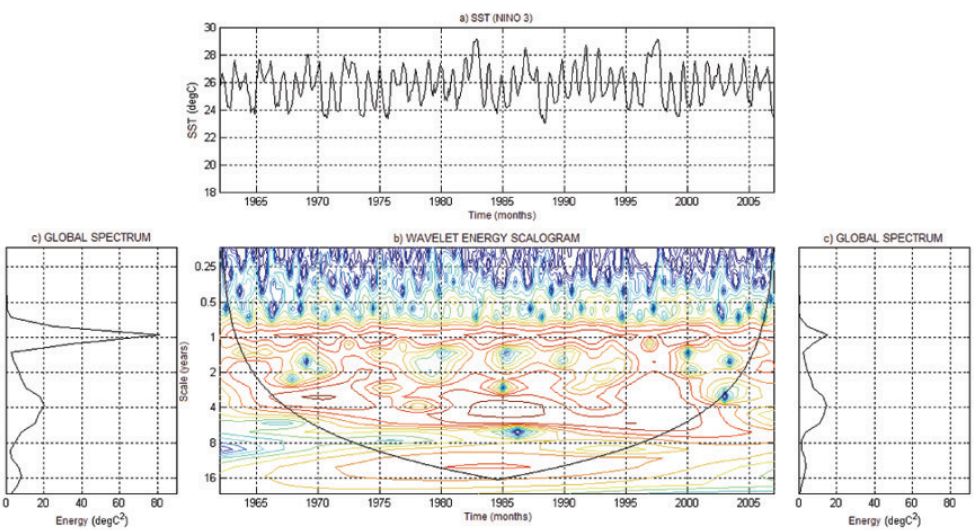

(2)
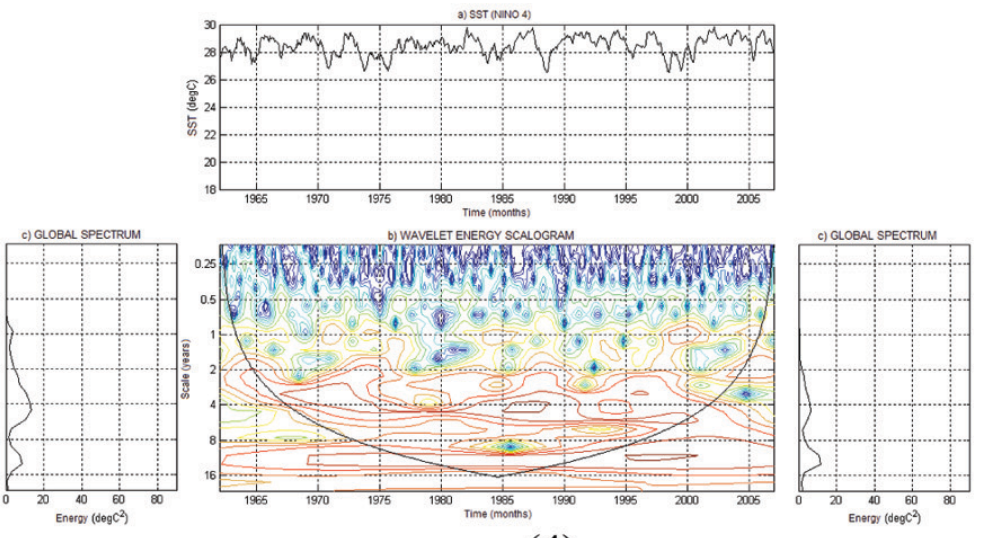

(4)

Figure 6 - Wavelet transform applied to the Pacific SST: (1) Niño 1+2; (2) Niño 3; (3) Niño 3.4, and (4) Niño 4.

variation is obviously linked to the alternations between solstices and equinoxes, but some climatic wave on decadal scale is also related to the North Atlantic SST modulation, even though to a very low degree. This fact indicates that the ocean not only modulates the climate, but can also be modulated by it to a much lesser extent, evidently.

The southern Atlantic Ocean has greater energy in the annual scale, while the energy associated with the other scales is negligible (Fig. 7.2b). Thus, the annual scale shows greater variability, representing an almost seasonal configuration.

In both cases, beyond the annual cycle, an oscillation on the decadal scale is part of the series; this is realized by the long-term oscillation seen at the end of the series.

\section{Relationship between SST and precipitation (PRP)}

The Pearson linear correlation coefficients $(r)$ were calculated using the standard deviations of precipitation and SST (Niño 1+2 areas, North and South Atlantic) to analyze the relationship be- tween the observed precipitation over the State of Paraíba and SST variability over the adjacent oceans, aiming at determining a statistically linear relationship between the two variables. The effectiveness of the correlation coefficients was determined by Student's $t$-test at significance level of 0.05 .

Over the Equatorial Pacific, only the Niño $1+2$ area was selected, since the WT technique showed energy weakening in the annual scale as it moves to the western Pacific, corroborating studies conducted by Xavier (2001).

In João Pessoa, the precipitation deviation variability showed an inverse and significant correlation with SST deviations over the Niño 1+2 (Fig. 8a and Table 3) area. It is observed that as SST in this region increases the precipitation in João Pessoa decreases, such as the El Niño strong events of 1982/83 and 1997/98, according to Trenberth classification (1997). In 1964, the deviations of João Pessoa and Niño 1+2 series are clearly opposites, the recorded precipitation was approximately $4000 \mathrm{~mm}$ and the SST around $22^{\circ} \mathrm{C}$ (Fig. 8a). La Niña, which began in May and lasted nine months, was also recorded that year. Therefore, the SST in 

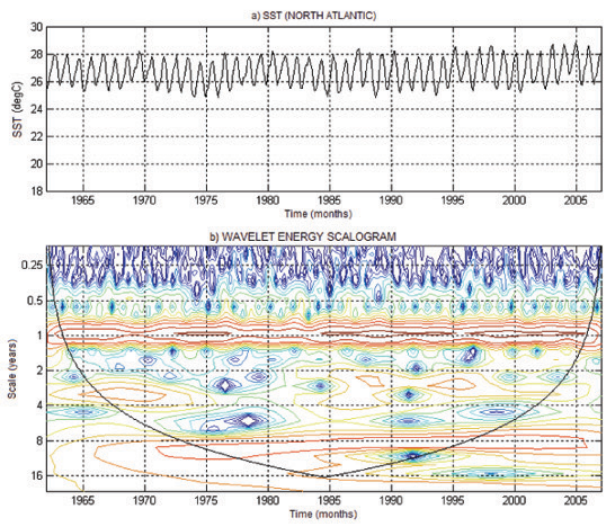

(1)
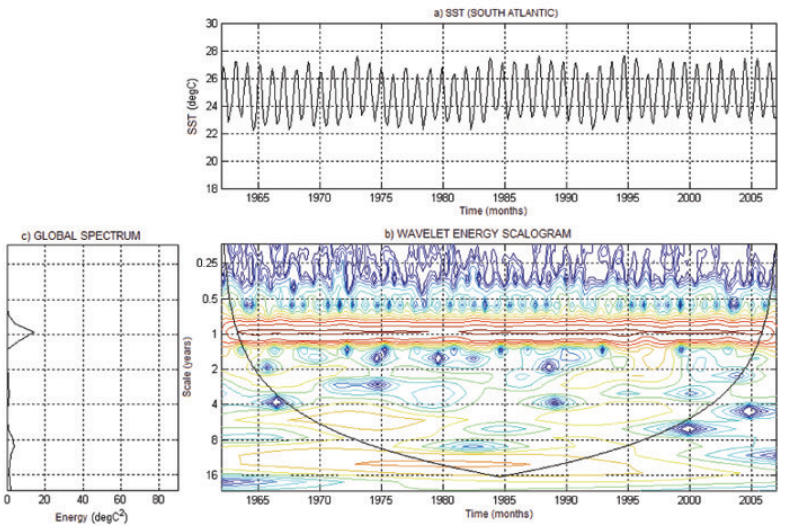

(2)

Figure 7 - Wavelet transform applied to the Atlantic SST: (1) North Atlantic and (2) South Atlantic.

the Pacific also contributed to increasing precipitation, since the wavelet analysis in João Pessoa showed some type of association of biennial, four-year and annual scale for that period, whose last scale represents both the El Niño and La Niña periods (Oliveira, 1999). In 1983, the total annual rainfall reduces greatly, reaching close to $1,000 \mathrm{~mm}$. One of the greatest recorded El Niño, classified as strong (Table 1), happened in 1982/83, lasted about 13 months and ended in July 1983.

Table 3 - Linear correlation coefficients between the SST anomalies of the Niño 1+2 and Atlantic Dipole with rainfall deviations in João Pessoa, Patos and Cajazeiras.

\begin{tabular}{|c|c|c|}
\hline & Niño 1+2 & Dipole \\
\hline João Pessoa & $-0.37^{*}$ & -0.24 \\
Patos & -0.17 & $-0.53^{\star}$ \\
Cajazeiras & -0.28 & $-0.46^{\star}$ \\
\hline
\end{tabular}

*95\% statistically significant.

Souza et al. (1997) showed that years of the positive phase of the dipole are associated with a predominance of negative deviation of precipitation. On the contrary, the years of negative dipole are associated predominantly with positive deviations of rainfall, as shown in Figure 8b. The mean deviations of precipitation tend to reduce lower intensity variations highlighting only events of greater magnitude (extreme events). Theoretically, very negative (positive) SST variation is associated with much (little) rain. Figure $8 \mathrm{~b}$ presents the relationship of the dipole with the rain in João Pessoa. The relationship "very negative/heavy rain" (very positive/little rain) appears in 1972/73/74/75 and 1983/84/85/86, showing that for these years the rainfall is possibly related to the Atlantic Dipole. Correlation analysis of the two series was not statistically significant, but it shows that there is an inverse relationship between the two (Table 3).
The relationship between the SST of the Niño 1+2 area and the precipitation in Patos shows a very unique case. The asymmetry of the series is observed only in some years, for example, 1982/83, 1984/85 and 1986/87 (Fig. 9a). During this period the wavelet analysis identified a strong energy core in the 4year scale of (Fig. 4), which suggests that the rainfall that season was correlated to ENSO events identified in this period, although not significantly (Table 3). The correlation between rainfall deviations in Patos and the Atlantic Dipole was - 0.53 , suggesting that modulation of Tropical Atlantic SST is more significant for the rainy regime of that region (Fig. 9b).

The relationship between precipitation in Cajazeiras and the SST in the Niño 1+2 and Atlantic Tropical areas is similar to that observed in Patos, including for the periods of asymmetries (Fig. 10 and Table 3). Both cities have in common the fact that they are best correlated to the Atlantic Dipole. According to Nimer (1979); Souza et al. (1997, 1998); Molion \& Bernardo (2002), among others, the rains in the northeast semiarid are strongly influenced by the ITCZ, and because the dipole directly affect its southern displacement, it is suggested that of all Paraíba regions the dipole affects the most the western part.

\section{CONCLUSIONS}

A WT of the Morlet function applied to climatological series of precipitation and SST was able to decompose the signal into multiple time scales and show that the series construction is part of complex interactions of fluctuations in different scales. The rain wavelet energy shows the relationships between the monthly, intraseasonal, semi-annual and annual scales, in which the interaction between three atmospheric weather systems on different 


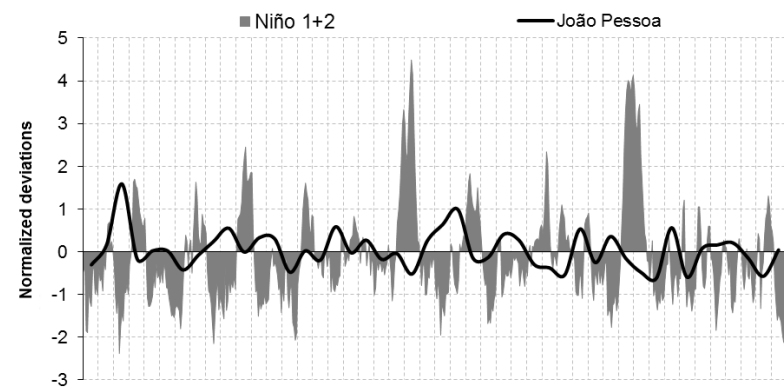

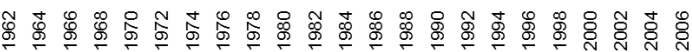

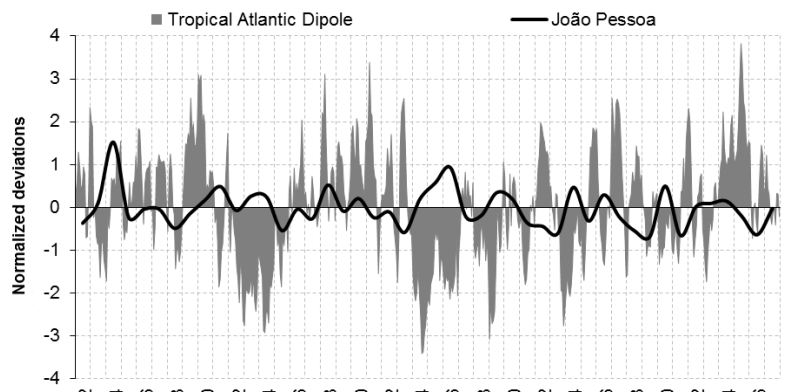

(a)

(b)

Figure 8 - Relationship between the SST of the Niño 1+2 area (a) and Atlantic Dipole (b) with rainfall in João Pessoa.

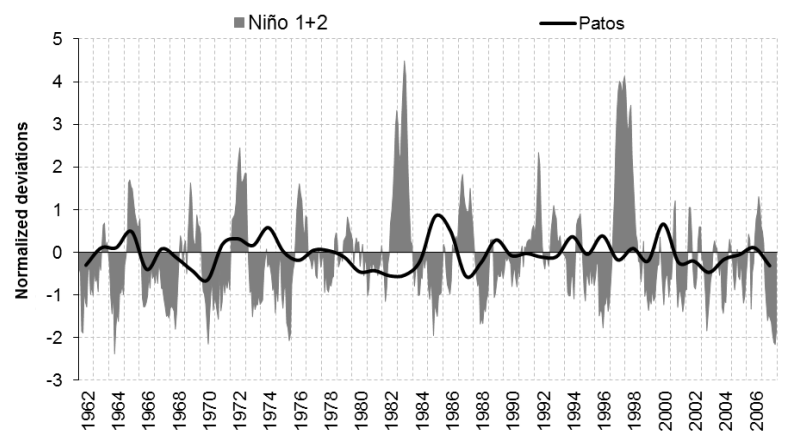

(a)

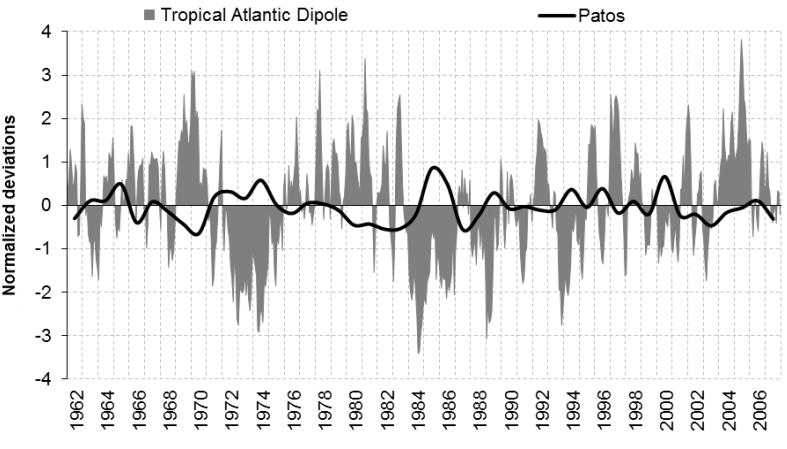

(b)

Figure 9 - Relationship between the SST of the Niño $1+2$ area (a) and Atlantic Dipole (b) with rainfall in Patos.

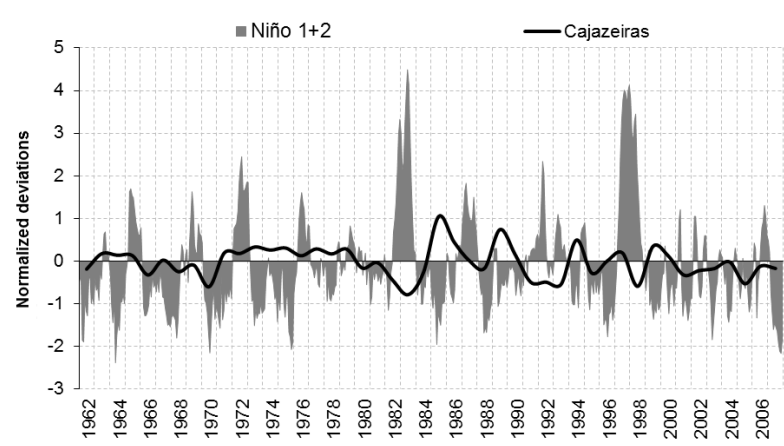

(a)

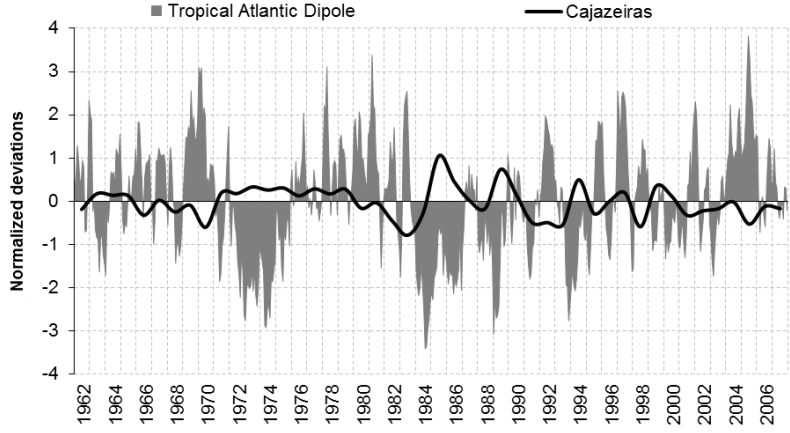

(b)

Figure 10 - Relationship between the SST of the Niño $1+2$ area (a) and Atlantic Dipole (b) with rainfall in Cajazeiras.

scales acted to produce high rainfall, such as the ITCZ, Eastern Waves and UTCVs. The years of severe drought have also been detected.

The analyses of the Equatorial Pacific SST showed that in the eastern part the annual scale is more intense due to the large variability of the annual cycle. Moving to the western Pacific, it was possible to detect that the annual scale weakens (almost canceling) and the decadal scale strengthens, which becomes more important in the series construction of this Pacific region. Therefore, the positive or negative SSTA configuration exceeds 
one year, being useful for climate forecasts. In the Atlantic, the SST series to the north and south were constituted mainly of two waves at different scales: one annual (more intense) and, another, decadal, which propagates throughout the study period.

The relationships between SST series and precipitation are more significant in certain years. The rainfalls are more related to the most intense ENSO events, especially in the central part of the state. The thermal gradient of the Atlantic was better associated with rainfalls in the western part, where the dipole interferes with the ITCZ and consequently, with the rainfall in the semi-arid region of Paraíba.

\section{ACKNOWLEDGMENTS}

The authors thank the Conselho Nacional de Desenvolvimento Científico e Tecnológico - CNPq for supporting this study.

\section{REFERENCES}

BOLZAN MJA. 2006. Transformada em ondeleta: Uma necessidade. Rev. Bras. de Ensino de Física, 28(4): 563-567.

BRAGA CC, BRITO JIB, SANSIGOLO CA \& RAO TVR. 2003. Tempo de resposta da vegetação às variabilidades sazonais da precipitação no Nordeste do Brasil. Rev. Bras. de Agrometeorologia, 11(1): 149-157.

BRITO JIB \& BRAGA CC. 2005. Chuvas no estado da Paraíba em 2004. Bol. Soc. Bras. Meteorol., 29(1): 27-32.

CERQUEIRA HDC. 2007. Análise harmônica de séries climatológicas de temperatura da superfície do mar nos oceanos Pacífico e Atlântico. 2008. Final graduation paper on Meteorology - Universidade Federal do Pará. Instituto de Geociências, Belém - Pará. 40 pp.

HASTENRATH S \& GREISHAR I. 1993. Circulation mechanisms related to Northeast Brazil rainfall anomalies. J. Geophys. Res., 98: 5093-5102.

KOUSKY VE. 1979. Frontal influences on Northeast Brazil. Mon. Wea. Rev., 107(9): 1140-1153.

KOUSKY VE. 1980. Diurnal rainfall variation in Northeast Brazil. Mon. Wea. Rev., 108(4): 488-498.

MEYER Y. 1993. Wavelets: algorithms and applications. SIAM, Philadelphia, $142 \mathrm{pp}$.

MOLION LCB \& BERNARDO SO. 2002. Uma revisão da dinâmica das chuvas no nordeste brasileiro. Rev. Bras. Meteorol., 17(1): 1-10.

MORETTIN PA. 1999. Ondas e ondeletas: da análise de Fourier à análise de ondeletas. São Paulo: editora da Universidade de São Paulo. 276 pp.

NIMER E. 1972. Climatologia da região Nordeste do Brasil: Introdução à Climatologia Dinâmica. Rev. Bras. Geografia, 34(2): 3-51.
NIMER E. 1979. Pluviometria e recursos hídricos dos Estados de Pernambuco e Paraíba. Rio de Janeiro: IBGE. 128 pp.

NOBRE P \& SHUKLA J. 1996. Variations of sea surface temperature, wind stress, and rainfall over the tropical Atlantic and South American. J. Climate, 9: 2464-2479.

OLIVEIRA GS. 1999. 0 El Niño e você: fenômeno climático. São José dos Campos - SP: Trastec. 155 pp.

PEZZI LP \& CAVALCANTI IFA. 2001. The relative importance of ENSO and tropical Atlantic sea surface temperature anomalies for seasonal precipitation over South America: a numerical study. Climate Dynamics, 17: 205-212.

RAO VB, LIMA MC \& FRANCHITO SH. 1993. Seasonal and interrannual variations of rainnfall over Eastern Northeast Brazil. J. Climate, 6(9): 1754-1763.

RASMUSSON EM \& CARPENTER TH. 1982. Variations in tropical sea surface temperature and surface wind fields associated with the Southern Oscillation/El Nino. Mon. Wea. Rev., 110: 354-384.

REYNOLDS RW, RAYNER NA, SMITH TM, STOKES DC \& WANG W. 2002. An improved in situ and satellite SST analysis for climate. J. Climate, 15: 1609-1625.

ROPELEWSKI CH \& HALPERT MS. 1989. Precipitation patterns associated with the high index phase of Southern Oscillation. J. Climate, 2(3): 268-284.

SERVAIN J. 1991. Simple climatic indices for the tropical Atlantic Ocean and some applications. J. Geophys. Res., 96: 15.137-15.146.

SOUZA EB, KAYANO MT, TOTA J, PEZZI L, FISCH G \& NOBRE C. 2000. On the influences of the El Niño, La Niña and Atlantic dipole pattern on the Amazonian rainfall during 1960-1998. Acta Amazonica, 30: 305-318

SOUZA EB, ALVES JMB \& REPELLI CA. 1997. Uma Revisão sobre a Influência dos Oceanos Pacífico e Atlântico na Variabilidade Pluviométrica do Semiárido Nordestino. Monitor Climático, 11(122): 7-17.

SOUZA EB, ALVES JMB \& REPELLI A. 1998. Influência dos oceanos Pacífico e Atlântico na estação chuvosa do Semiárido Nordestino. Rev. Bras. Agrometeorol., 6(2): 277-283.

TORRENCE C \& COMPO GP. 1998. A practical guide to wavelet analysis. Bull. Amer. Meteor. Soc., 79: 61-78.

TRENBERTH MR. 1997. The definition of the El Niño. Bull. Amer. Meteor. Soc., 78(12): 2771-2777.

UVO CRB. 1989. Zona de Convergência Intertropical (ZCIT) e sua relação com a precipitação da região norte do Nordeste do Brasil. Master dissertation on Meteorology, Instituto Nacional de Pesquisas Espaciais - INPE, São José dos Campos, 82 pp. 
VITORINO MI. 2002. Análise das oscilações intrasazonais sobre a América do sul e oceanos adjacentes utilizando a análise de ondeletas. Doctorade thesis on Meteorology - Programa de Pós-graduação em Meteorologia, Instituto Nacional de Pesquisas Espaciais. 344 pp.

VITORINO MI, BRAGA CC \& BRITO JBB. 2006. Análise da variabilidade de baixa frequência da precipitação sobre o estado da Paraíba. In: XIV Congresso Brasileiro de Meteorologia, 2006, Florianópolis. Proceed- ings... Salvador: SBMET, 2006. CD-ROM.

WENG H \& LAU K-M. 1994. Wavelet, period doubling, and timefrequency localization with application to organization of convection over the tropical Western Pacific. J. Atmos. Sci., 51: 2523-2541.

XAVIER TB. 2001. Tempo de chuva: estudos climáticos e de previsão para o Ceará e Nordeste Setentrional. Fortaleza: ABC Editora. 476 pp.

Recebido em 16 maio, 2012 / Aceito em 6 maio, 2013

Received on May 16, 2012 / Accepted on May 6, 2013

\section{NOTES ABOUT THE AUTHORS}

Célia Campos Braga. Meteorologist and holds a Master's degree in Meteorology from the Universidade Federal da Paraíba (UFPB). Ph.D. in Natural Resources from the Universidade Federal da Paraíba (UFPB). Currently, works as Associate Professor of undergraduate and graduate courses in Meteorology, Universidade Federal de Campina Grande (UFCG). Has experience in Geosciences with an emphasis on Climatology and Remote Sensing, in the following fields: vegetation dynamics, precipitation, vegetation parameters, climate variability, time series simulation and multivariate analysis.

Jonathan Castro Amanajás. Holds a degree in Mathematics from the Universidade Federal do Amapá (UNIFAP) and a Master's degree in Meteorology, from the Universidade Federal de Campina Grande (UFCG). Currently, is a Ph.D. student in Meteorology, Universidade Federal de Campina Grande (UFCG). Has experience in Geosciences with an emphasis on Climatology, in the following topics: statistical climatology, climate variability, time series analysis and multivariate analysis.

Hallan David Velasco Cerqueira. Meteorologists from the Universidade Federal do Pará (UFPA). Holds a Master's degree in Meteorology, from the Universidade Federal de Campina Grande (UFCG). Has experience in Geosciences with an emphasis on Agrometeorology, Synoptic Meteorology and Climatology.

Maria Isabel Vitorino. Meteorologist from the Universidade Federal da Paraíba (UFPB). M.Sc. in Meteorology from the Universidade de São Paulo (USP). Ph.D. in Meteorology from the Instituto Nacional de Pesquisas Espaciais (INPE). Currently, works as Adjunct Professor of undergraduate and graduate meteorology courses in Environmental Sciences, College of Meteorology, Universidade Federal do Pará (UFPA). Has experience in Geosciences with emphasis on Climatology and Atmospheric Dynamics. 